\title{
Calcium-Dependent Nitric Oxide Synthase Activity in Rat Thymocytes
}

\author{
M. T. Cruz,* A. Carmo,† A. P. Carvalho, † and M. C. Lopes*,1 \\ *Faculdade de Farmácia, U niversi dade de Coimbra and †Centro de Neurociências, \\ Universi dade de Coimbra, 3030 Coimbra Codex, Portugal
}

We examined the conversion of $L-\left[{ }^{3} \mathrm{H}\right]$ arginine to $L-$ $\left[{ }^{3} \mathrm{H}\right]$ citrulline in lysate from rat thymocytes, which was dependent on $\mathrm{Ca}^{2+}$ and cofactors ( $F A D, \mathrm{BH}_{4}, \mathrm{NADPH}$ ). Removal of $\mathrm{Ca}^{2+}$ of the medium, reduced the total $L-$ $\left[{ }^{3} \mathrm{H}\right]$ citrulline formation by about $97 \%$. The L- $\left[{ }^{3} \mathrm{H}\right]-$ citrulline formation was completely inhibited by the NO synthase inhibitors, $\mathbf{N}^{G}$-nitro-L-arginine and $\mathbf{N}^{\mathrm{G}}$ monomethyl-L-arginine, with values for $I C_{50}$ of $1.2 \mu \mathrm{M}$ and $19.4 \mu \mathrm{M}$, respectively. In intact thymocytes, the $L$ $\left[{ }^{3} \mathrm{H}\right] c i t r u l l i n e$ formation was dependent on the intracellular $\mathrm{Ca}^{2+}\left(\left[\mathrm{Ca}^{2+}\right]_{i}\right)$ concentration. Increasing the extracellular free- $\mathrm{Ca}^{2+}$ concentration up to $1.5 \mathrm{mM}$, was accompanied by an increase in $\left[\mathrm{Ca}^{2+}\right]_{i}$ inside the thymocytes and there was a parallel increase in the intracellular L-[ $\left.{ }^{3} \mathrm{H}\right]$ citrulline formation, which reached a maximal value of $371.2 \mathrm{nM}$ of $\left[\mathrm{Ca}^{2+}\right]_{i}$. Addition of $\mathrm{N}^{\mathrm{G}}$ nitro-L-arginine to the medium, completely inhibited the formation of L-[ $\left.{ }^{3} \mathrm{H}\right]$ citrulline. The immunolabeling study revealed that $15 \%$ of the thymocytes isolated from rat thymus constitutively expressed the endothelial isoform of NO synthase. $\odot 1998$ Academic Press

In mammalian cells, nitric oxide (NO) and citrulline are stoichiometrically generated from $\mathrm{L}$-arginine ( $\mathrm{L}$ Arg) in an enzymatic reaction catalysed by the nitric oxide synthase (NOS). To date, two constitutive isoforms of NO synthase, which are regulated by physiological changes in the intracellular calcium concentra-

\footnotetext{
${ }^{1}$ To whom correspondence and reprint requests should be addressed. Fax: + 351-39-480117. E-mail: celeste@imagem.ibili.uc.pt.

Abbreviations: $\left[\mathrm{Ca}^{2+}\right]_{\text {out, }}$ extracellular $\mathrm{Ca}^{2+}$ concentration; $\left[\mathrm{Ca}^{2+}\right]_{\mathrm{i}}$ intracellular $\mathrm{Ca}^{2+}$ concentration; $\mathrm{BH} 4,6-(\mathrm{R}, \mathrm{S})-5,6,7,8,-$ tetrahydrobiopterin; ecNOS, endothelial constitutive nitric oxide synthase; FAD, flavine adenine dinucleotide; FITC, fluorescein isothiocyanate; $I_{50}$, half-maximal inhibitory concentration; L-Arg, L-arginine; LMetArg, $N^{G}$-monomethyl-L-arginine; L-NOArg, $N^{G}$-nitro-L-arginine; LPS, lipopolysaccharide; NADPH, $\beta$-nicotinamide adenine dinucleotide phosphate; NO, nitric oxide; NOS, nitric oxide synthase; PBS, phosphate-buffer saline.
}

tion $\left(\left[\mathrm{Ca}^{2+}\right]_{i}\right)$, have been identified, the neuronal and the endothelial NOS isoforms $(1,2)$.

In contrast to the neuronal and endothelial cells, in which the presence and the functional importance of the constitutive enzymes have been demonstrated, in lymphocytes neither the presence nor the biological role of the NO synthase isoforms is known. There is some question as to whether the ability of Iymphocytes synthesise $\mathrm{NO}$; thus it has been reported either that T Iymphocytes can be triggered to produce NO (3-9), or that lymphocytes produce a very low level of NO $(10,11)$ even in the presence of lipopolysaccharide (LPS) (12) and cytokines (13), which induce the expression of the inducible isoform of NO synthase in many cell types (1).

The thymus is the organ where the $T$ cell development occurs (14). Despite the extensive production of Iymphocytes in the thymus, relatively few of those cells mature to the single-positive ( $\mathrm{CD} 4^{+}$or $\mathrm{CD}^{+}$) stage and migrate to the peripheral blood, and little is known about the selection process which result in the transition of certain immature $\mathrm{T}$ lymphocytes (CD4 ${ }^{+} \mathrm{CD}^{+}$, double-positive cells) to mature and viable single-positive cells (15). Re cent studies, suggest that depending on the concentration of NO, it may be either toxic or protective for signalling in thymocyte devel opment (16-20).

Previous studies provided evidence for the presence of the constitutive endothelial isoform of NO synthase in T lymphocytes from peripheral blood (5). However, there are no literature reports addressing whether the thymocytes contain the constitutive isoform of NO synthase. Therefore, we investigated whether thymocytes express the constitutive isoform of the NO synthase, and studied the relationship between the rate of citrulline (or NO) formation and the $\left[\mathrm{Ca}^{2+}\right]_{i}$ in intact thymocytes.

\section{MATERIAL AND METHODS}

Isolation of thymocytes from rat thymus. Thymocytes were isolated from five-week male Wistar rats, as previously described (21), in a sodium medium containing $132 \mathrm{mM} \mathrm{NaCl}, 4 \mathrm{mM} \mathrm{KCl}, 6 \mathrm{mM}$ 
glucose, $1.4 \mathrm{mM} \mathrm{MgCl}_{2}, 10 \mathrm{mM}$ HEPES, pH 7.4 and $0.1 \%$ bovine serum albumin fatty acid free (Sigma Chemical Co., St. Louis, MO, U.S.A.). The cells in suspension were counted in a T540 Coulter Counter, and the cell viability was evaluated by the trypan blue exclusion test, after the isolation procedure. A total of $96-98 \%$ of the freshly isolated thymocytes routinely excluded trypan blue.

To obtain the lysate of freshly isolated thymocytes, the cells isolated from each thymus (approximately $400 \times 10^{6}$ cells) were resuspended in $2 \mathrm{ml}$ of cold water and then lysed, at $4^{\circ} \mathrm{C}$, using a ultrasonic cell disrupter (sonifier cell disrupter, Model W140).

Identification of CD2 positive cells by flow cytometric analysis. Thymocytes in suspension ( $10^{6}$ cells) were incubated with $10 \mu$ l of mouse anti-rat CD2:FITC (isotype IgG2a) (Serotec, Oxford, England), or mouse IgG2a negative control:FITC (Serotec, Oxford, England), during $15 \mathrm{~min}$, in a total volume of $0.1 \mathrm{ml} \mathrm{PBS}$. Then, the cells were washed and resuspended in $0.8 \mathrm{ml}$ PBS. The fluorescence was analysed by flow cytometry using a EPICS XL (Coulter) with a $550 \mathrm{~nm} \mathrm{DL}$ and a $525 \mathrm{~nm}$ BP filters.

Measurement of the NO synthase activity by the $L-\left[{ }^{3} \mathrm{H}\right]$ citrulline formation. The enzyme activity of NO synthase was determined in the lysate of thymocytes, under the following conditions: $400 \mu \mathrm{g}$ protein of the lysate, $10 \mathrm{nM} \mathrm{L}-\left[{ }^{3} \mathrm{H}\right]$ arginine $(69 \mathrm{Ci} / \mathrm{mmol}$ ) (Amersham Laboratories, Buckinghamshire, England), cofactors (1 mM NADPH, $5 \mu \mathrm{M}$ FAD or $20 \mu \mathrm{M} \mathrm{BH}_{4}$ ) (Sigma Chemical Co., St. Louis, MO, U.S.A.), and free $\mathrm{Ca}^{2+}(100 \mu \mathrm{M})$, in a total volume of $200 \mu \mathrm{l}$. In some experiments varying concentrations (from 0.001 to $500 \mu \mathrm{M}$ ) of $\mathrm{N}^{\mathrm{G}}$ monomethyl-L-arginine (L-MetArg) or $N^{G}$-nitro-L-arginine ( $L$ NOArg) (Sigma Chemical Co., St. Louis, MO, U.S.A.) were added to the reaction mixture (Sigma Chemical Co., St. Louis, MO, U.S.A.). After incubating for $20 \mathrm{~min}$, the reactions were terminated by the addition of $1.8 \mathrm{ml}$ of ice cold stop buffer. $\mathrm{L}-\left[{ }^{3} \mathrm{H}\right]$ citrulline formation was measured in $2 \mathrm{ml}$ applied on the top of $0.8 \mathrm{ml}$ Dowex AG50WX8 ( $\mathrm{Na}^{+}$form) (Serva, Heidelberg, Germany) columns, previously equilibrated with $20 \mathrm{mM}$ sodium acetate, pH 5.5 containing $1 \mathrm{mM}$ L-citrulline (Sigma Chemical Co., St. Louis, MO, U.S.A.), $2 \mathrm{mM}$ EDTA and $0.2 \mathrm{mM}$ EGTA (stop solution), as previously described (22). The counts were corrected by a blank assay running in the absence of calcium and in the presence of $0.1 \mathrm{mM}$ EGTA.

To determine the NO synthase activity in intact thymocytes, the cells in suspension $\left(11 \times 10^{6}\right)$ were incubated at $37^{\circ} \mathrm{C}$, for $20 \mathrm{~min}$, in the sodium medium containing $10 \mathrm{nM} \mathrm{L-}\left[{ }^{3} \mathrm{H}\right]$ arginine and different
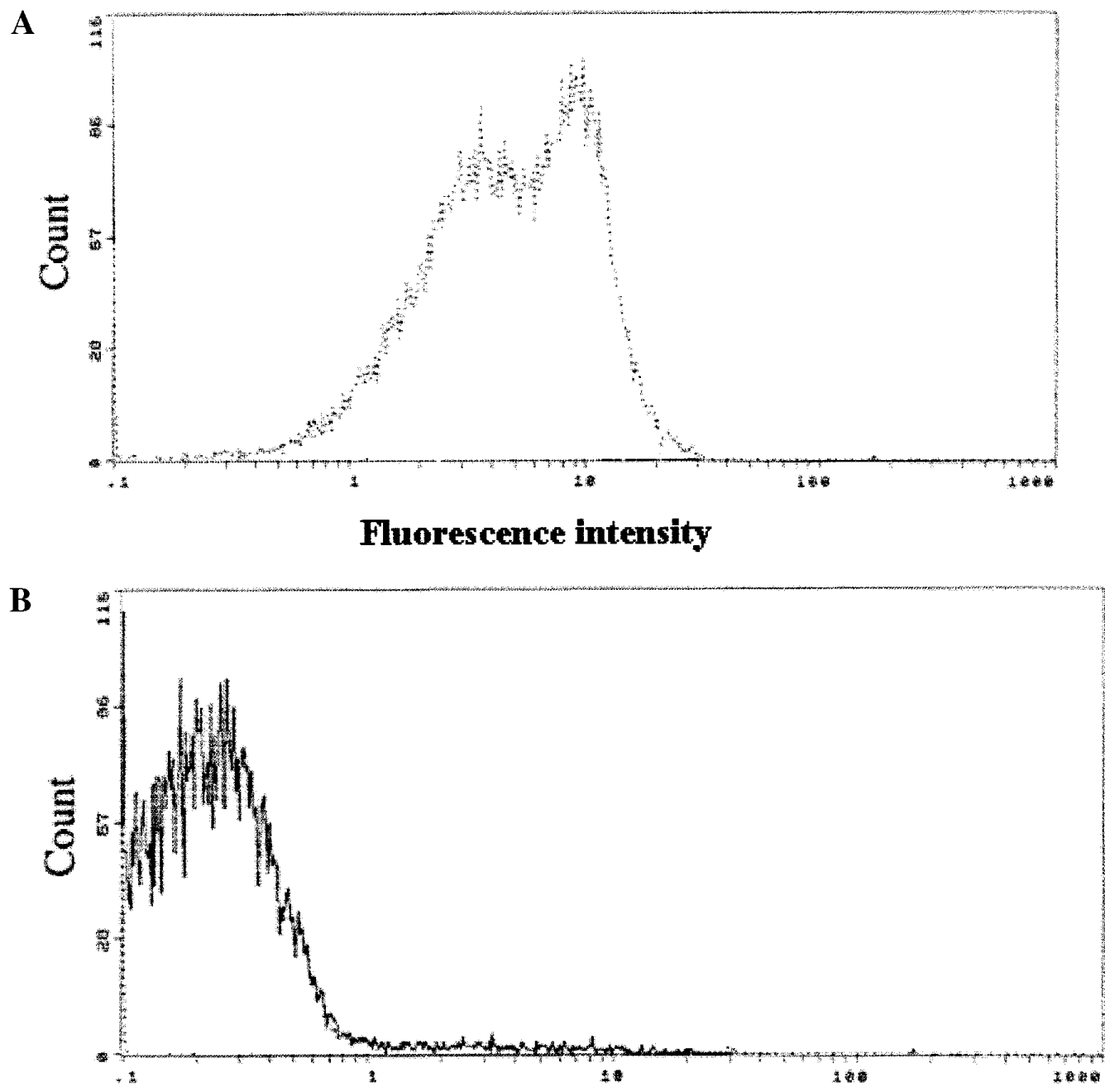

Fluorescence intensity

FIG. 1. Percentage of CD2 positive cells isolated from rat thymus. Thymocytes in suspension (106 cells) were incubated with the mouse anti-rat CD2:FITC (A), or mouse IgG2a negative control:FITC (B), and the fluorescence was analysed by flow cytometry, as described in materials and methods. The figure is representative of three separated experiments. 
concentrations of $\mathrm{Ca}^{2+}$ or L-NOArg, as specified in the legends of the figures. Incubations were terminated by rapid centrifugation $(200 \mathrm{~g} /$ $8 \mathrm{~min}$ ) in eppendorf microcentrifuge (Eppendorf 5402 ), at $4^{\circ} \mathrm{C}$, and by rinsing of the pellet twice with $1 \mathrm{ml}$ of cold sodium medium. Then, the cells were disrupted with $1.5 \mathrm{ml}$ of water and centrifuged at $15800 \mathrm{~g} / 5 \mathrm{~min}$. Aliquots of $50 \mu \mathrm{l}$ of the supernatant were used to measure the radioactivity incorporated into the cells in a liquid scintillation counter. L- $\left[{ }^{3} \mathrm{H}\right]$ citrulline formation by the cells was measured in $1 \mathrm{ml}$ of the supernatant, which was applied on the top of 0.8 $\mathrm{ml}$ Dowex AG50WX-8 ( $\mathrm{Na}^{+}$form) columns, previously equilibrated as mentioned above. The counts were corrected for the blank assay in the absence of calcium and in the presence of $1 \mathrm{mM}$ EGTA.

The concentration of free $\mathrm{Ca}^{2+}$ in the incubation medium was quantified as previously described (23).

Measurement of cytosolic fre $\mathrm{Ca}^{2+}$ concentration. Thymocytes $\left(3 \times 10^{7} \mathrm{cell} / \mathrm{s} / \mathrm{ml}\right.$ ) were incubated in Hepes-buffered RPMI-1640 (Sigma, USA) with $1 \mu \mathrm{M}$ Indo-1-AM (Molecular Probes, Leiden, The Netherlands), for $30 \mathrm{~min}$, at $37^{\circ} \mathrm{C}$. The cells were sedimented and washed once with fresh culture medium. Aliquots of $4 \times 10^{6}$ cells were ressuspended in sodium medium containing different concentrations of $\mathrm{Ca}^{2+}$, and incubated, for $15 \mathrm{~min}$, at $37^{\circ} \mathrm{C}$. Measurements of cytosolic $\mathrm{Ca}^{2+}$ concentrations were performed at $37^{\circ} \mathrm{C}$ with a spectrofluorimeter $\left(\lambda_{\text {ex }} 335\right.$ $\left.\mathrm{nm}, \lambda_{\mathrm{em}} 410 \mathrm{~nm}\right)$. Calibration was performed with $1 \mathrm{mM}$ ionomycin (Calbiochem-Boehringer, San Diego, U.S.A.) and $\mathrm{MnCl}_{2}$ (1M) (Calbiochem-Boehringer, San Diego, U.S.A.), and intracellular $\mathrm{Ca}^{2+}$ concentrations were calculated as previously described (24).

I dentification of theendothelial isoform of NO synthaseby immunocytochemistry. Cell smears were fixed in acetone for $5 \mathrm{~min}$. N onpecific binding was blocked by incubation in normal rabbit serum in PBS (1:20) for $30 \mathrm{~min}$ at room temperature. Cells were then incubated $2 \mathrm{~h}$ at room temperature, with a rabbit polyclonal antibody directed against human endothelial constitutive NO synthase (ecNOS) and human neuronal constitutive NO synthase (1:75) (Transduction Laboratories, Lexington, U.S.A.). After rinsing with PBS the cells were incubated with biotinylated rabbit anti-mouse IgG (Dako, Copenhagen, Denmark) at a 1:200 solution for $30 \mathrm{~min}$. Following a second rinsing in PBS, cells were further incubated with the avidin-biotinylated complex for $30 \mathrm{~min}$. After a final rinsing, peroxidase activity was visualized using diaminobenzidine $(6 \mathrm{mg}$ per $10 \mathrm{ml}$ of PBS) and $\mathrm{H}_{2} \mathrm{O}_{2}$ ( $1 \mu \mathrm{l}$ per $10 \mathrm{ml}$ of solution). Cell smears were counterstained with hematoxylin and mounted. All experiments included omission of primary antibodies as negative controls.

\section{RESULTS}

Before measuring the NO synthase activity in rat thymocytes, we characterised the cell population isolated from juvenile rat thymus in terms of the CD2 positive cells. Assuming that thymocytes are the only cells in the thymus that express the CD2 surface marker (25), our results obtained by labelling the cells with monoclonal mouse anti-rat CD2:FITC antibody (Fig. 1A), permit concluding that $96 \%$ of the cells isolated from rat thymus were thymocytes.

The results of the experiments with the lysate of freshly isolated thymocytes indicate that thymocytes contained the $\mathrm{Ca}^{2+}$-dependent NO synthase (Fig. 2A). The enzyme activity required the presence of $\mathrm{Ca}^{2+}$ and cofactors (NADPH, FAD and $\mathrm{BH}_{4}$ ) for the maximal activity, which corresponds to the formation of $446 \pm 0,4 \mathrm{fmol}$ dtrulline/mg protein/20 min (Fig. 2A). Removal of $\mathrm{Ca}^{2+}$, by omission of external $\mathrm{CaCl}_{2}$ and addition of EGTA (0.1 $\mathrm{mM}$ ) to the incubation medium, reduced the total NO synthase activity from $100 \pm 3.5 \%$ to $3 \pm 1.2 \%$ (Fig. $2 A$ ).

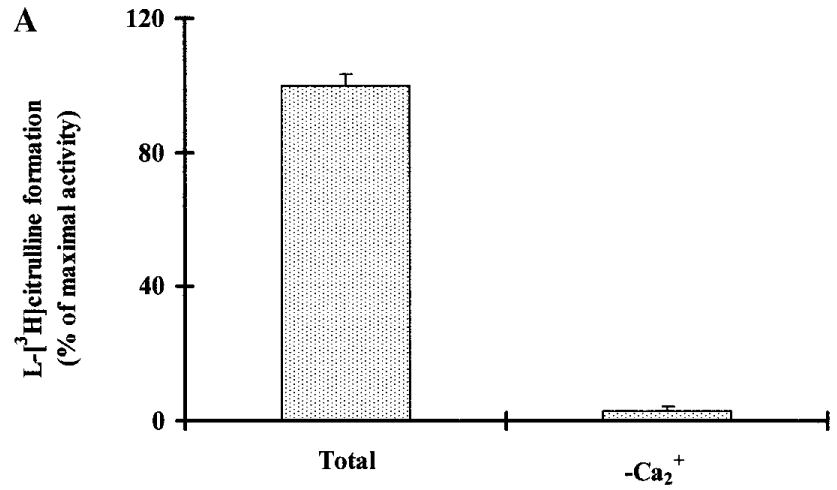

Total: $100 \mu \mathrm{M} \mathrm{Ca}_{2}^{+} ; 1$ mM NADPH; $5 \mu \mathrm{M} \mathrm{FAD;} 20 \mu \mathrm{M} \mathrm{BH}_{4}$

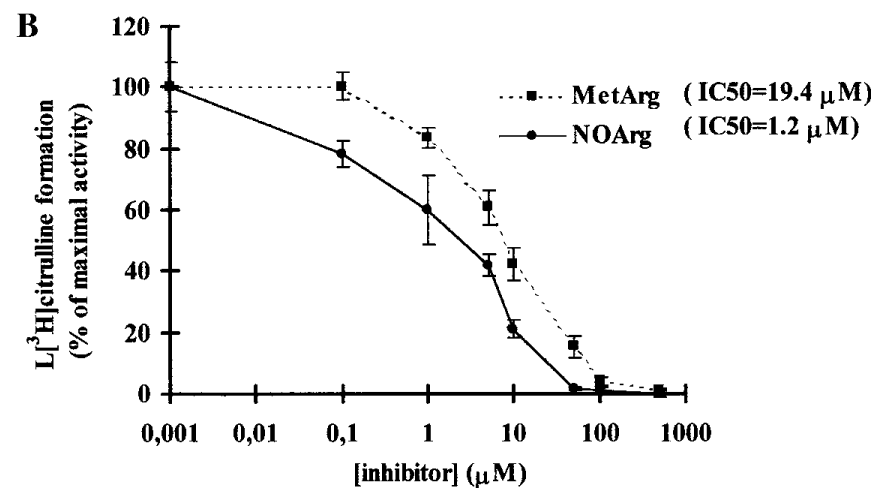

FIG. 2. The $\mathrm{Ca}^{2+}$-dependent $\mathrm{NO}$ synthase activity in Iysate of thymocytes. The NO synthase activity was measured in the lysate of thymocytes (400 $\mu \mathrm{g}$ of protein), in a sodium medium containing $10 \mathrm{nM}$ of $\mathrm{L}-\left[{ }^{3} \mathrm{H}\right] \mathrm{Arg}$, cofactors (1 mM NADPH, $5 \mu \mathrm{M} \mathrm{FAD}$ or $20 \mu \mathrm{M} \mathrm{BH}_{4}$ ) and $100 \mu \mathrm{M}$ free $\mathrm{Ca}^{2+}$ concentration (total enzyme activity). The effect of $\mathrm{Ca}^{2+}$ (Fig. 2A) and of different concentrations of unlabeled L-NOArg or of L-MetArg (Fig. 2B) was evaluated as described in material and methods. The maximal activity (100\%) corresponds to $446 \pm 0.4 \mathrm{fmol}$ of L$\left[{ }^{3} \mathrm{H}\right]$ citrulline $/ \mathrm{mg}$ protein/20 min. Values are mean \pm SEM for three independent experiments, each done in triplicate.

As shown in Fig. 2B, both L-MetArg and L-NOArg, which inhibit the NO synthase activity by competing with L-Arg (2), are potent inhibitors of citrulline formation in the lysate of rat thymocytes. However, L-NOArg was a more potent inhibitor than L-MetArg. The halfmaximal inhibitory concentration $\left(\mathrm{IC}_{50}\right)$ values for $\mathrm{L}$ NOArg and L-MetArg are $1.2 \mu \mathrm{M}$ and $19.4 \mu \mathrm{M}$, respectively (Fig. 2B), as calculated by the Hill plots.

In a previous study, we determined the time-course of the $\mathrm{L}-\left[{ }^{3} \mathrm{H}\right]$ arginine uptake by intact thymocytes (data not shown), and we found that the maximal incorporation of $\mathrm{L}-\left[{ }^{3} \mathrm{H}\right]$ arginine into the thymocytes occurs within the first $20 \mathrm{~min}$ of time incubation. To study the relation between the $\mathrm{L}-\left[{ }^{3} \mathrm{H}\right]$ arginine uptake and $\mathrm{NO}$ synthase activity in intact thymocytes, we determined the effect of both L-NOArg and L-MetArg on the L$\left[{ }^{3} \mathrm{H}\right.$ ]arginine uptake and on the conversion of $\mathrm{L}-\left[{ }^{3} \mathrm{H}\right]-$ arginine to $\mathrm{L}-\left[{ }^{3} \mathrm{H}\right]$ citrulline. The results indicated that $0.1 \mathrm{mM} \mathrm{L}-$-MetArg inhibited the $\mathrm{L}-\left[{ }^{3} \mathrm{H}\right]$ arginine uptake 

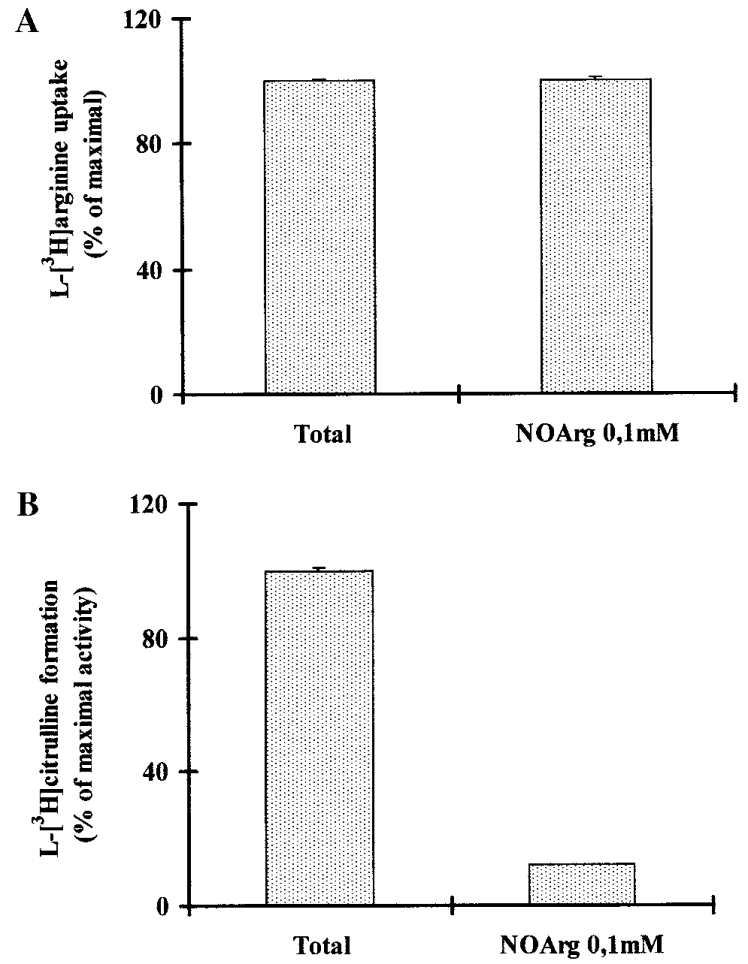

FIG. 3. Effect of the NO synthase inhibitor, L-NOArg, on the $\mathrm{L}-\left[{ }^{3} \mathrm{H}\right]$ arginine uptake and on the $\mathrm{Ca}^{2+}$-dependent formation of $\mathrm{L}$ $\left[{ }^{3} \mathrm{H}\right]$ citrulline in rat thymocytes. Cells $\left(11 \times 10^{6}\right)$ were incubated during $20 \mathrm{~min}$ in the presence of $10 \mathrm{nM}$ of $\mathrm{L}-\left[{ }^{3} \mathrm{H}\right]$ arginine, $1 \mathrm{mM}$ of free calcium and $0.1 \mathrm{mM}$ of $\mathrm{L}-\mathrm{NOA}$. The data on the $\mathrm{L}-\left[{ }^{3} \mathrm{H}\right]$ arginine transport (A), and on the $\mathrm{Ca}^{2+}$-dependent $\mathrm{L}-\left[{ }^{3} \mathrm{H}\right]$ citrulline formation (B), were obtained from the same samples, as described in material and methods. Values are mean \pm SEM for three independent experiments, each done in triplicate.

by $52.3 \pm 1.5 \%$ (data not shown) after cell incubation with radiolabelled L-Arg during $20 \mathrm{~min}$, whereas 0.1 $\mathrm{mM}$ of L-NOArg had no detectable influence on $\mathrm{L}-\left[{ }^{3} \mathrm{H}\right]-$ arginine uptake, but it inhibited NO synthase activity inside the cells (Fig. 3A and Fig. 3B). When thymocytes were incubated in the absence of L-NOArg, the maximal NO synthase activity (100\%) was $55 \pm 0.69 \mathrm{fmol}$ citrulline $/ 11 \times 10^{6}$ cells $/ 20 \mathrm{~min}$. The addition of $0.1 \mathrm{mM}$ L-NOArg to the incubation medium reduced by $87.9 \pm 0.35 \%\left(6.7 \pm 0.35 \mathrm{fmol}\right.$ citrulline $/ 11 \times 10^{6} \mathrm{cells} / 20$ $\mathrm{min}$ ) the enzyme activity (Fig. 3B).

We also analysed the relation between the extracelluIar $\mathrm{Ca}^{2+}$-concentration and both the $\left[\mathrm{Ca}^{2+}\right]_{i}$ and the NO synthase activity in thymocytes. Freshly isolated thymocytes in $\mathrm{Ca}^{2+}{ }^{-}$free medium had low $\left[\mathrm{Ca}^{2+}\right]_{i}$, usually between 60-80 nM, and no NO synthase activity was detected in this experimental condition (Fig. 4B). Addition of $0.1 \mu \mathrm{M} \mathrm{Ca}^{2+}$ to thymocytes increased the $\left[\mathrm{Ca}^{2+}\right]_{i}$ to $88.3 \pm 7.8 \mathrm{nM}$, and the $\mathrm{L}-\left[{ }^{3} \mathrm{H}\right]$ citrulline formation increased to $5.8 \pm 0.148 \mathrm{fmol} L-\left[{ }^{3} \mathrm{H}\right]$ citrulline $/ 11 \times 10^{6} \mathrm{cells} / 20$ min. When the value of the $\left[\mathrm{Ca}^{2+}\right]_{\text {out }}$ in the reaction mixture was $1500 \mu \mathrm{M}$, the value of $\left[\mathrm{Ca}^{2+}\right]_{i}$ became
$371.2 \pm 28.7 \mathrm{nM}$, and a maximal value of $\mathrm{L}-\left[{ }^{3} \mathrm{H}\right] \mathrm{citrulline}$ formation, $55 \pm 0.69 \mathrm{fmol} \mathrm{L}-\left[{ }^{3} \mathrm{H}\right]$ citrulline $/ 11 \times 10^{6}$ cells/ 20 min was observed (Fig. 4). These results show that thymocytes constitutively expressed the $\mathrm{Ca}^{2+}$-dependent NO synthase.

Immunocytochemical staining of thymocytes was used to identify the NO synthase isoform in these cells. The results obtained by light microscopy of thymocytes labelled with antibodies against the two $\mathrm{Ca}^{2+}$-dependent NOS (neuronal and endothelial) revealed that about $15 \% \pm 0.94$ of the thymocytes isolated from rat thymus constitutively express the endothelial isoform of NO synthase (Fig. 5A), and negative controls al ways showed negative staining (Fig. 5B). No labelling was found in thymocytes stained with polyclonal antibody against the neuronal (type I) isoform of NO synthase, which labelled neuronal cells in culture used as positive control (data not shown).

\section{DISCUSSION}

In this work, we show that rat thymocytes isolated from thymus of juvenile rats contained the endothelial
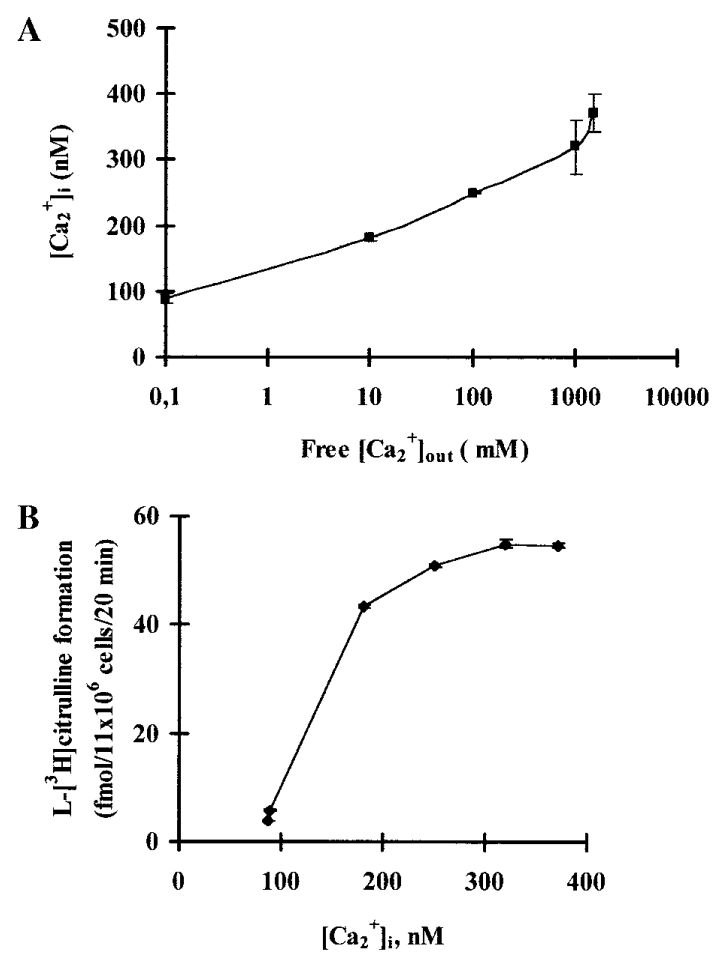

FIG. 4. Effect of $\left[\mathrm{Ca}^{2+}\right]_{\text {out }}$ on the $\left[\mathrm{Ca}^{2+}\right]_{\mathrm{i}}$, and on the NO synthase activity in rat thymocytes. Intracellular $\mathrm{Ca}^{2+}$ concentration was monitored using $1 \mu \mathrm{M}$ Indo-1-AM, after cells incubation with the $\mathrm{Ca}^{2+}$ indicator dye during $30 \mathrm{~min}(\mathrm{~A})$. $\mathrm{L}-\left[{ }^{3} \mathrm{H}\right]$ citrulline formation $(\mathrm{B})$ was determined after cells incubation, during $20 \mathrm{~min}$, with $10 \mathrm{nM}$ of $\mathrm{L}-\left[{ }^{3} \mathrm{H}\right]$ arginine and varying concentrations of extracellular free $\mathrm{Ca}^{2+}(0-1500 \mu \mathrm{M})$. The results are expressed as fmol of citrulline/ $11 \times 10^{6} \mathrm{cells} / 20 \mathrm{~min}$. Values are mean \pm SEM for three independent experiments, each done in triplicate. 

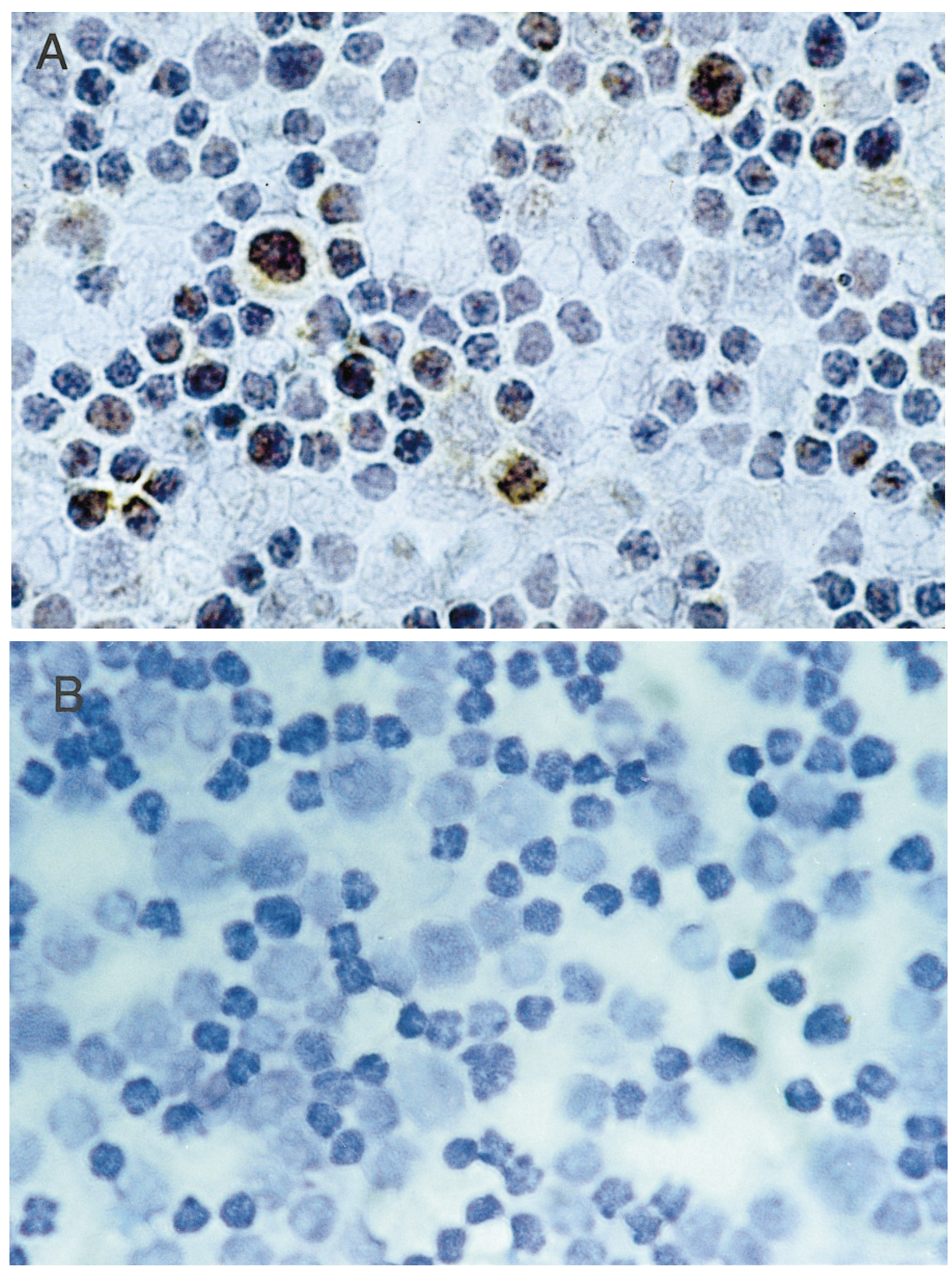

FIG. 5. I mmunocytochemistry for the endothelial NO synthase isoform. I mmunocytochemistry for NO synthase was performed with anti-ecNOS, as described in materials and methods. These figures are the representative results of four independent experiments. (A), Light microscopy of thymocytes labelled for ecNOS; (B), Control IgG shows no labelling. Original magnification 200x.

constitutive isoform of NO synthase. The citrulline formation in the lysate of thymocytes required $\mathrm{Ca}^{2+}$ and the specific cofactors for maximal NO synthaseactivity.
This activity was completely blocked by the two L-Arg analogous, L-MetArg and L-NOArg (Fig. 2B), which competitively inhibit the NO synthase activity (2). In 
intact thymocytes, L-NOArg inhibited the citrulline formation, without affecting the uptake of tritiated LArg (Fig. 3), whereas L-MetArg inhibited both the NOS activity and the L-Arg transport (data not shown). Similar pattern of inhibition was previously observed in neuronal cells $(26,27)$. These results, together with the finding that increasing external free $\mathrm{Ca}^{2+}$-concentration up to $1.5 \mathrm{mM}$ was accompanied by an increase in citrulline formation (Fig. 4), demonstrate that thymocytes constitutively express the $\mathrm{Ca}^{2+}$-dependent $\mathrm{NO}$ synthase.

Previous studies revealed that nitrite production was not detected in either thymocytes or T helper cell clones (13). These results correlate with our previous observations showing that the nanomolar concentrations of NO, produced in the supernatant of several cell cultures, was not detected when a spectrophotometric assay, based on the Griess reaction (28), was used.

I mmunocytochemical staining of thymocytes, with polyclonal antibody against ecNOS, revealed the presence of the endothelial NO synthase isoform in these cells (Fig. 5). It was recently reported that Iymphocytes from peripheral blood contain the enzyme ecNOS $(5$, 8), although the functional role of this enzyme in lymphocytes is unknown. In this work, we demonstrated the presence of ecNOS in $15 \%$ of the total population of thymocytes isolated from rat thymus (Fig. 5). From the studies on $T$ cell selection in thymus, it was concluded that $10-15 \%$ of the intrathymic thymocytes are single positive $\left(\mathrm{CD}_{4}{ }^{+} \mathrm{CD}_{8}{ }^{-}\right.$or $\left.\mathrm{CD}_{4}{ }^{-} \mathrm{CD}_{8}{ }^{+}\right)$thymocytes and migrate to the periphery $(29,30)$. This opens the question as to whether the ecNOS positive thymocytes are the cells released into the blood circulation. I ndeed, the development of immunocompetent T-lymphocytes from immature precursor cells take place in thethymus (14), and NO generated by ecNOS may play an important role in modulating the process of maturation of thymocytes within the microenvironment of the thymus. Although the role of NO produced by ecNOS in the regulation of thymocytes development and maturation is not known, the small amount of NO produced by thymocytes can act as an auto-regulatory molecule during thymocyte development. To clarify this point it is important to have information about the regulation of ecNOS expression in different subsets of thymocytes at different stages of development in the thymus.

\section{ACKNOWLEDGMENTS}

The authors thank Dra. Fátima Brandão for the help provided in the characterisation of thymocytes by flow cytometry. This work was supported by the Foundation for Science and Technology, Portugal.

\section{REFERENCES}

1. Knowles, R. G., and Moncada, S. (1994) Biochem. J . 298, 249258.
2. Griffith, O. W., and Stuehr, D. J . (1995) Annu. Rev. Physiol. 57, 707- 36.

3. Kirk, S. J ., Regan, M. C., and Barbul, A. (1990) Biochem. Biophys. Res. Commun. 173, 660-665.

4. Taylor-Robinson, A. W., Liew, F. W., Severn, A., Xu, D., McSorley, S. J ., Garside, P., Padron, J ., and Philips, R. S. (1994) Eur. J . Immunol. 24, 980-984.

5. Reiling, N., Krönche, R., Ulmer, A.J ., Gerdes, J ., Flad, H. D., and Hauschildt, . (1996) Eur. J . Immunol. 26, 511- 516.

6. Benbernou, N., Esnault, S., Shin, H. C., Fekkar, H., and Guenounou, M. (1997) I mmunol. 91, 361-8.

7. Esaki, T., Hayashi, T., Muto, E., Yamada, K., Kuzuya, M., and I guchi, A. (1997) Atherosclerosis 128, 39- 46.

8. Sciorati, C., Rovere, P., Ferrarini, M., Heltai, S., Manfredi, A. A., and Clementi, E. (1997) J . Biol. Chem. 272, 23211- 5.

9. Taylor-Robinson, A. W. (1997) Biochem. Biophys. Res. Comm. 233, 14- 19.

10. Bauer, H., J ung, T., Tsikas, D., Stichtenoth, Frölich, J . C., and Neumann, C. (1997) Immunol. 90, 205-211.

11. Shoker, A. S., Yang, H., Murabit, M. A., J amil, H., al-Ghoul, A., and Okasha, K. (1997) Mol. Cell Biochem. 171, 75-83.

12. Kondo, S., I shiguro, N., I wata, H., Nakashima, I., and I sobe, K. (1993) Biochem. Biophys. Res. Comm. 197, 1431- 1437.

13. Thüring, H., Stenger, S., Gmehling, D., Röllinghoff, M., and Bogdan, C. (1995) Eur. J . Immunol. 25, 3229- 34.

14. von Boehmer, H. (1997) Immunol. Today 18, 260- 262.

15. Moore, N. C., J enkinson, E. J ., and Owen, J . J . T. (1992) Eur. J . Immunol. 22, 2533- 2537.

16. Fehsel, K., Krönche, K. D., Meyer, K. L., Huber, H., Wahn, V., and Kolb-Bachofen, V. (1995) J . Immunol. 155, 2858- 2865.

17. Salgo, M. G., Squadrito, G. L., and Pryor, W. A. (1995) Biochem. Biophys. Res. Comm. 215, 1111- 1118.

18. Sandau, K., and Brüne, B. (1996) Cell. Signal. 8, 173- 177.

19. Hortelano, S., Dallaporta, B., Zamzami, N., Hirsch, T., Susin, S. S., Marzo, I., Boscá, L., and Kroemer, G. (1997) FEBS Letters 410, 373- 377.

20. Tai, X. G., Toyo-oka, K., Yamamoto, N., Yashiro, Y., Mu, J ., Hamaoka, T., and Fujiwara, H. (1997) J . Immunol. 158, 4696- 703.

21. Grinstein, S., Cohen, S., Goetz-Smith, J.D., and Dixon, S.J . (1984) Am. J . Physiol. 247, C293.

22. Bush, P. A., Gonzalez, N. E., Griscavage, J . M., and I gnarro, L. J . (1992) Biochem. Biophys. Res. Comm. 185, 960- 966.

23. Fabiato, A., and Fabiato, F. (1979) J . Physiol. (Paris) 75, 463505.

24. Gelfand, E. W., Cheung, R. K., and Grinstein, S. (1986) FEBS Letters 242, 391- 396.

25. Howard, F. D., Ledbetter, J . A., Wong, J ., Bieber, C. P., Stinson, E. B., and Herzenberg, L. A. (1981) J . I mmunol . 126, 2117- 2122.

26. Westergaard, N., Beart, P. M., and Schousboe A. (1993) J . Neurochem. 61, 364- 367.

27. Lopes, M. C., Cardoso, S. A., Schousboe, A., and Carvalho, A. P. (1994) Neuroscience Letters 181, 1-4.

28. Green, L. C., Wagner, D. A., Glogowski, J ., Skipper, P. L., Wishnok, J.S., and Tannenbaum, S. R. (1982) Anal. Biochem. 126, $131-138$.

29. Scollay, R., and Godfrey, D. I . (1995) Immuunol. Today 16, 268 274.

30. Chow, S. C., Snowden, R., Orrenius, S., and Cohen, G. M. (1997) FEBS Letters 408, 141- 146. 